of the Federation of American Scientists believes that "the RRW and Complex 2030 programmes are not only unnecessary. They also undercut efforts to convince non-nuclear nations to forgo nuclear weapons and to convince new weapons states such as India and Pakistan to refrain from developing additional warheads."

The concept of nuclear deterrence is dead, according to former US commander-in-chief of the Strategic Command, General James Cartwright, now Vice Chairman of the Joint Chiefs of Staff. In place of mutually assured destruction, Hodge and Weinberger describe strategic deterrence, an "amorphous concept" that covers everything from "a public relations campaign to a bunker buster". The authors puzzle over why officials still cannot provide answers to the basic questions of how many nuclear weapons are wanted, what they will be used against, and when.

An equally puzzled Congress is stalling on the issue. It has cut the budget for RRW and the Complex 2030 expansion in response to the concerns of scientists and citizens, but the projects are still alive. Managing the programmes and their effects on global nonproliferation efforts will be one of the first items on the next president's nuclear agenda.

Travelling beyond the vast weapons complex of the United States, the authors visit the countries you would expect, and some you would not. The former Soviet nuclear cities, mirrors of Oak Ridge and Los Alamos, are even more decayed and dilapidated. Security analysts have been troubled by unsecured facilities and underemployed weapons scientists since the fall of the Soviet Union. Joint programmes between the United States and Russia have secured around half of the poorly protected weapons and materials in the former Soviet states, but much material is still vulnerable to terrorist theft. It also leaves unaddressed a legacy of nuclear pollution. Kazakhstan, the authors discover, gave up its deployed nuclear weapons but still suffers from nuclear isotopes in its soil.

Hodge and Weinberger succeeded in entering Iran, whose nuclear energy programme could bring it a weapons capability. The Iranian guides leading a tour of the Isfahan Uranium Conversion Facility, which I visited in 2005, tried to convince the authors that the programme was peaceful and transparent. "Our trip," they conclude, "could be taken as a sign of openness, but it could just as easily be interpreted as cynical propaganda." They give a nuanced understanding of the programme from the Iranian point of view - both as a source of national pride and a burden that keeps the country sanctioned and isolated. Iran, like other nations, has yet to come to terms with the nuclear programme it has created.

A Nuclear Family Vacation has its flaws. The opening chapters drag, and the discussion sometimes meanders, determined by the material the authors were able to get rather than what is most important. Overall, the book sparkles with anecdotes and insights. It is well worth the trip.

Joseph Cirincione is the president of the

Ploughshares Fund and author of Bomb Scare: The History and Future of Nuclear Weapons.

\title{
Memories revisited
}

\section{In Search of Memory: The Neuroscientist Eric Kandel \\ Film directed by Petra Seeger \\ Showing in Austria.}

German filmmaker Petra Seeger met neuroscientist Eric Kandel by chance in Berlin two years ago, and was enthralled by his research and life story. An Austrian Jew forced to flee the Nazis in 1939, Kandel (pictured) is still coming to terms with his traumatic past. In Search of Memory, Seeger's 95-minute documentary of the mischievous 79 year old, premiered on 26 May in Vienna, Kandel's childhood home.

In 2000, Kandel shared the Nobel Prize for Physiology or Medicine for his work on how neurons lay down memories. The film weaves Kandel's recollections and the science of learning and memory. Seeger accompanies him to Vienna to seek out his family's old apartment, his father's toy shop and other poignant places that he has avoided for fear of stirring up pain. Seeger's camera follows Kandel in mid closeup. Re-enactments of his childhood are mixed with archive footage from 1930s Austria and contemporary scenes shot in his laboratory at Columbia University in New York.

Kandel recalls on screen the jubilant welcome of Hitler's troops as they marched into Vienna in March 1938. The following November, a few days after his ninth birthday, he witnessed the horrors of Kristallnacht, when rioters destroyed synagogues and Jewish premises. Instructed to leave their house, his family returned two weeks later to find that everything had been stripped from it, even his birthday toys. He recalls the collusion of many Austrians with the Nazis and the lack of support, or even sympathy, from former non-Jewish friends.

Those enduring memories fuelled Kandel's desire to understand the biological basis of memory. His approach was unfashionably reductionist. He chose as his model organism the sea slug Aplysia californica, which has just a few large nerve cells and a robust reflex - it withdraws its gills in response to stimulation. Kandel showed that the sea slug can learn to modify this reflex when repeatedly stimulated, and that the change is caused by strengthening

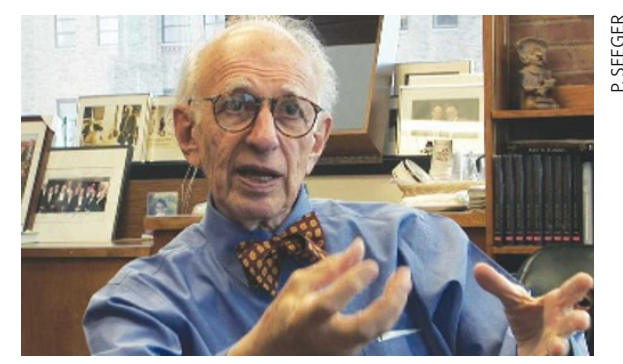

of the synapses, the regions where neurons connect with each other.

Seeger mirrors that reductionist approach in her filming. She eschews high-tech animations, relying on Kandel to explain his science with only a flip chart and a large plastic model of the brain. His lab seems busy and his colleagues look happy: young researchers relate their own discoveries with moving enthusiasm. Scientists come across as vibrant people with pasts, sensitivities and futures - with stories to tell.

The naive viewer may not take home many scientific details, but the documentary conveys the breadth of neuroscience and the scientific process. It describes different types of memory that arise in distinct parts of the brain, and the fundamental cellular process of synapse strengthening. Kandel's story shows that to reach the truth, you sometimes need to go back to basics before reconstructing the big picture.

Kandel laughs a lot as he confronts his past. In one memorable sequence in New York, he asks an old man seated on a chair in the street if he remembers his father's store. "What's your problem?" the old man barks. But within a minute they banter about their age, and laugh so infectiously that the audience laughs too. In another scene, Kandel's eyes brim with tears.

The strength and weakness of In Search of Memory, named after Kandel's book of the same name, is that it is uncritical, a love affair with this petite, demanding genius. The film manipulates its viewers into adoration. Scientists outside Kandel's lab barely get a mention. But the warmth of the film, together with the political and scientific importance of the subject, more than compensate.

Alison Abbott is Nature's Senior European Correspondent. 